\title{
Assessment of Ecological State of the Velikaya River Delta Based on Hydrochemical Indicators and Structure of Phytoplankton
}

\author{
Tatiana Drozdenko, Sergei Mikhalap, Larisa Nikolskaya, Anna Chernova \\ Pskov State University, Natural Sciences, Medical and Psychological Education faculty \\ Address: 21cSovetskaya st., Pskov, 180000, Russia.
}

\begin{abstract}
The basis of the existence of freshwater ecosystems is phytoplankton, which produces most of the primary biological production, participates in repair processes and provides a wide range of ecosystem services. The short life cycle and high speed metabolism of microalgae make them ideal objects for ecological monitoring.

The aim of the present study is to research the ecological state of the Velikaya river delta based on the species composition of phytoplankton community and some hydrochemical parameters.

The sample collection for phytoplankton study and physicochemical measurements was carried out in summer 2016 at five stations representing different ecological locations of the Velikaya river delta.

One hundred sixty five species taxa of microalgae belonging to 8 phylums were identified during the research: Bacillariophyta (37\%), Chlorophyta (33.9\%), Cyanophyta/Cyanobacteria (9.7\%), Chrysophyta (6.1\%), Euglenophyta (6.1\%), Cryptophyta (3\%), Dinophyta (3\%), Xanthophyta (1.2\%).

The values of Shannon index indicate the average complexity of the microalgae communities structure. Values of Margalef index characterize the Velikaya river delta as an area of high species richness. Compared to the previous studies, a significant increase in the level of information diversity is observed, indicating an increase in the number of possible flows of substance and energy in the ecosystem. Dynamics of biogen substances in the water shows a slight increase of their concentrations.

Ecological and geographical analysis proves that absolute dominance of cosmopolitan freshwater forms is typical for the algoflora of the Velikaya river delta. In relation to the pH-reaction inhabitants of neutral and slightly alkaline water dominate. Pantle-Buck saprobity index is applied for water quality assessment, which shows beta-mesosaprobic water quality in the ecosystem. Thus, the water of the Velikaya river delta could be referred to the category of moderately polluted water (class II of water quality). This is confirmed by the data of hydrochemical analysis.
\end{abstract}

Keywords: phytoplankton, species diversity, ecological monitoring, algae, ecological assessment, Velikaya river delta.

\section{INTRODUCTION}

Nowadays it is difficult to monitor of the structural changes in natural ecosystems, which are the most important providers of ecosystem services and essential elements of existence of human civilization. Nowadays conservation of natural ecosystems is possible only if there is an effective environmental governance program based on integrated ecological monitoring [1, 2]. Local and regional ecosystems play a key role in the interaction with anthropogenic objects as they neutralize various pollutants by natural biochemical processes. Aquatic ecosystems play an essential role providing a wide range of ecosystem services, such as food, clean water, waste treatment, nutrient cycling, carbon accumulation and recreational resources. Due to high metabolism rate and complex structural and functional organization aquatic ecosystems are sensitive to urbanization and climate change [3, 4].

Microalgae communities are vital for aquatic ecosystems. Phytoplankton organisms are important components of aquatic communities because they make the primary ecological production. Phytoplankton communities are first to respond to initial changes in aquatic ecosystems by changing structural and energetic components. That makes them the key objects for studying the energy balance of ecosystems and water quality biomonitoring $[5,6]$.

I.The Velikaya river delta located $8 \mathrm{~km}$ northwest from Pskov is chosen as a model ecosystem. It is a unique natural complex where water masses of the Velikaya river and its catchment area (before it joins in the Lake Peipus) mix and transform. The shape of the delta is almost trianglular, its median length is 4.2 $\mathrm{km}$ and width is about $4 \mathrm{~km}$. Its total area is $2.7 \mathrm{~km}^{2}$. 
Delta is represented by a complex of low, marshy islands separated by bayous [5].

Border position of Velikaya river delta determines some features of its climate regime. The studied area differs from neighboring territories and has better conditions for vegetation due to its milder and shorter winter and longer and sunnier summer seasons as well as to a favorable balance of heat and moisture. The combination of these factors enables the potential the Velikaya river delta to form aquatic ecosystems primary production. It should be noted that this area is constantly exposed to local antropogenic impacts [5].

The purpose of the study was to research the ecological state of the Velikaya river delta based on hydrochemical parameters and structure of phytoplankton.

The tasks:

1. To investigate the hydrochemical parameters of the Velikaya river delta;

2. to study the taxonomic composition of phytoplankton Velikaya river delta in the summer period;

3. to give the ecological and geographical characteristics of phytoplankton organisms;

4. to conduct a saprobiological analysis of the Velikaya river delta for indicator organisms;

5. to study the parameters of the alpha and beta diversity of phytoplankton communities in the sampling points.

\section{MATERIALS AND METHODS}

Sampling points

Collection of hydrochemical and hydrobiological materials was carried out in summer period 2016 in the Velikaya river delta at five sampling points (Fig. 1.):

1 - Vaymenka;

2 - Bolshaya Listovka;

3 - Srednyaya;

4 - Gorki;

5 - Murovitsy.

Water sampling is made according to GOST 31861-2012 (Water ... 2014). Hydrochemical study included quantitative determination of nitrite, nitrate, ammonium, phosphate ions, hydrogen carbonate and carbonate ions, biochemical oxygen demand within five days $\left(\mathrm{BOD}_{5}\right)$, total phosphorus concentrations $\left(\mathrm{P}_{\text {total }}\right)$, total nitrogen $\left(\mathrm{N}_{\text {total }}\right)$, total iron $\left(\mathrm{Fe}_{\text {total }}\right)$. Analysis were performed using titration and spectrophotometric methods in an accredited laboratory (accreditation certificate FSA (Federal Service for accreditation) № RA.RU.21AH24 by 22.10.2015) according to methods of series PND F (Environmental normative documents Federal) [7-14].

Hydrobiological and hydrochemical samples were collected with a plastic sampler (volume 0.5 liter) at the depth of $0,3-0.5 \mathrm{~m}$. Samples of water were taken simultaneously. Phytoplankton samples were fixed with a $40 \%$ formalin solution and treated by the standard procedure [15-17]. If possible, all algae were identified to species level using the Carl Zeiss Axio Lab microscope. A1. It was done with help of domestic and foreign references [18-22].

Determination of the number of phytoplankton in 1 liter of water was carried out by standard methods [23].

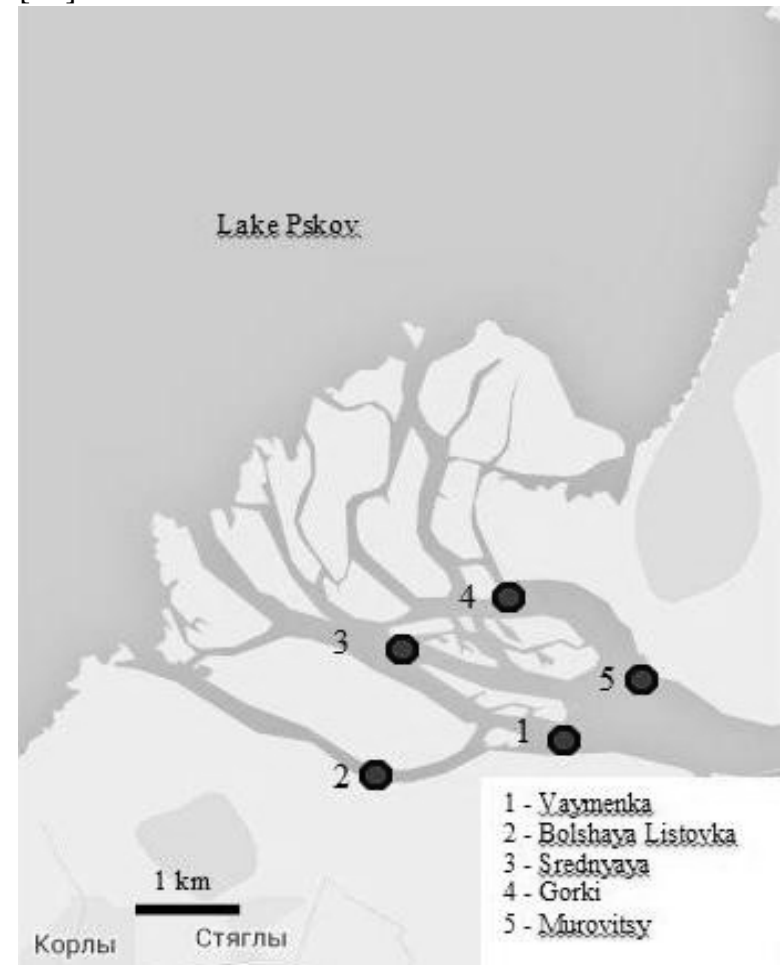

Fig. 1. Sampling points in the Velikaya river delta

Data from a number of researches and monographs were used to select ecological groups of microalgae and determining their ecological and geographical characteristics were used data from a number of monographs [24, 25]. Saprobic index was calculated by the method Pantle and Bukk in Sladechek modification [26].

For studying alpha-diversity of microalgae community were calculated Shannon index, Simpson index, Margalef index and Pielou's evenness index. Similarity of algae taxonomic composition in sampling points were analyzed using by Sørensen index [27]. A procedure of cluster analysis points was used to compare species structure of algae communities in different samples [28]. All stages of the statistical data processing were conducted by Statistica 8.0 and MO Excel programs.

\section{RESULTS AND DISCUSSION}

Hydrochemical analysis was conducted in summer period 2016 on at all five sampling points. During the analysis were determined following indicators of water quality were determined (Tab. 1). 
Table 1

Hydrochemical Analysis Results of Velikaya River Delta

\begin{tabular}{|c|c|c|c|c|c|}
\hline \multirow{2}{*}{ 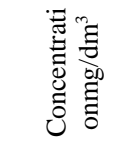 } & \multicolumn{5}{|c|}{ Sampling points } \\
\hline & 1 & 2 & 3 & 4 & 5 \\
\hline $\mathrm{NO}_{2}^{-}$ & 0.043 & 0.087 & 0.044 & 0.048 & 0.035 \\
\hline $\mathbf{N H}_{4}{ }^{+}$ & 1.110 & 0.930 & 1.100 & 1.040 & 0.540 \\
\hline $\mathrm{NO}_{3}^{-}$ & 0.675 & 0.776 & 0.588 & 0.620 & 0.670 \\
\hline $\mathbf{N}_{\text {общ. }}$ & 1.036 & 0.931 & 1.006 & 0.965 & 0.582 \\
\hline $\mathrm{PO}_{4}{ }^{3-}$ & 0.061 & 0.063 & 0.050 & 0.055 & 0.063 \\
\hline $\mathbf{P}_{\text {об̆щ. }}$ & 0.020 & 0.021 & 0.017 & 0.018 & 0.021 \\
\hline БПК 5 & 0.855 & 0.624 & - & - & 1.984 \\
\hline $\mathrm{Fe}_{\text {общщ. }}$ & 0.170 & 0.140 & 0.110 & 0.110 & 0.160 \\
\hline $\mathrm{HCO}_{3}^{-}$ & 141.52 & 150.67 & 123.22 & 103.09 & 128.71 \\
\hline $\mathrm{CO}_{3}{ }^{2-}$ & 1.2 & 1.2 & 1.2 & 1.2 & 19.2 \\
\hline
\end{tabular}

The concentration of $\mathrm{HCO}^{3-}$ at the sampling points "Vaymenka", "B. Listovka" and "Murovitsy" somewhat higher than at the other sampling points. The decrease in concentration of bicarbonates in other points from $140-150 \mathrm{mg} / \mathrm{dm}^{3}$ to $103-120 \mathrm{mg} / \mathrm{dm}^{3}$ is due to the high concentration of humic acids formed in the process of swamping in middle and lower delta. In general, the comparative analysis of the mineral composition of the Velikaya river delta from 1992 to 2016 indicates to its slight change. By major-ion waters of the Velikaya river delta were characterized as bicarbonate-calcium. The concentration of carbonates was 16 times higher at the point "Murovitsy" than at the other sampling points. It can be explained by Devonian limestone deposits and change of river current in this area: the river here flows slower, thereby increasing the concentration of the mineral components of streamflow.

Assessment of nitrogen compounds affecting the trophic level of the waterbody revealed increased concentration of ammonium at the Velikaya river delta. In all sampling points except "Murovitsy" (0.54 $\mathrm{mg} / \mathrm{dm} 3$ ), the level of ammonium-ions is almost same and exceeds the threshold limit value (TLV) twice. The presence of ammonium-ions in concentrations above background values, indicates a high organic content in the water. The concentration of nitrate-ions in all investigated areas of the delta was almost the same $-0.6-0.7 \mathrm{mg} / \mathrm{dm}^{3}$ with a slight increase in the "B. Listovka" point. Also in "B. Listovka" area exceeds admitted standards slightly. Nitrites, in addition to ammonium are indicators of processes of organic decomposition and mineralization.
The values of iron concwntration were exceeded at sampling points "Vaymenka" and "Murovitsy". These sampling points are located the closest to the urban infrastructure and contain significant amounts of iron pumped into the water by municipal wastewater.

The most essential condition for the life of organisms in the aquatic environment is the concentration of dissolved oxygen. Results of chemical analysis showed that the level of dissolved oxygen was satisfactory for the existence of aquatic organism - 8.5-9.0 mg/dm .

Chemical monitoring data are consistent with hydrobiological studies and demonstrate the ability of Delta for natural self-purification. This is occurring in the first place by vegetation, including phytoplankton organisms.

During the study of the qualitative composition of summer phytoplankton of the Velikaya river 165 taxa below the rank of genus, belonging to 8 phylums, 11 classes, 18 orders, 43 families, 90 genera (Tab. 2) delta were identified.

Table 2

Taxonomic Composition of Phytoplankton of Velikaya River Delta (Summer, 2016)

\begin{tabular}{|l|c|c|c|c|c|}
\hline \multicolumn{1}{|c|}{ Phylum } & Class & Order & Family & Genus & Taxa \\
\hline Bacillariophyta & 2 & 5 & 15 & 29 & 61 \\
\hline Chlorophyta & 3 & 5 & 17 & 32 & 56 \\
\hline Cyanophyta & 1 & 3 & 6 & 11 & 16 \\
\hline Chrysophyta & 1 & 1 & 1 & 7 & 10 \\
\hline Euglenophyta & 1 & 1 & 1 & 6 & 10 \\
\hline Cryptophyta & 1 & 1 & 1 & 2 & 5 \\
\hline Dinophyta & 1 & 1 & 1 & 2 & 5 \\
\hline Xanthophyta & 1 & 1 & 1 & 1 & 2 \\
\hline Total & $\mathbf{1 1}$ & $\mathbf{1 8}$ & $\mathbf{4 3}$ & $\mathbf{9 0}$ & $\mathbf{1 6 5}$ \\
\hline
\end{tabular}

The distribution by phylums were as follows: Bacillariophyta - 61 (37.0\%), Chlorophyta - 56 (33.9\%), Cyanobacteria - $16(9.7 \%)$, Chrysophyta $10(6.1 \%)$, Euglenophyta - 10 (6.1\%), Cryptophyta $5(3.0 \%)$, Dinophyta - 5 (3.0\%), Xanthophyta -2 $(1.2 \%)$ taxa. Xanthophyceae algae were represented by only two species of the same genus - Tribonema affine (G. S.West) G. S. West. И Tribonema vulgare Pasch.

It was found that 38 families $(88.4 \%)$ belong to the three phylums: Chlorophyta (39.5\%), Bacillariophyta $(34.9 \%)$ and Cyanobacteria (14.0\%) and includes the $133(80.6 \%)$ of taxon. The dominance of these phylums is typical for waterbodies of the North-Western region of Russia [29, 30].

Analysis of phytoplankton composition at all sampling points shows (Fig. 2.) that the greatest number of taxa observed in the "Vaymenka" - 131 
taxa $(79.4 \%$ of the total number of species), and the smallest - in the "Murovitsy" - 65 (39.4\%).

In all the study areas of the delta diatomaceousgreen algalflora complex dominated. At the study point "Murovitsy", unlike the others points, where the third place was taken by the Cyanobacteria, Chrysophyta dominated. No representatives of Euglenophyta were found at the point "Srednaya". Euglenophyta and Xanthophyta were not detected at "Murovitsy".

The results of ecological and geographical analysis of phytoplankton are presented in Tab. 3.

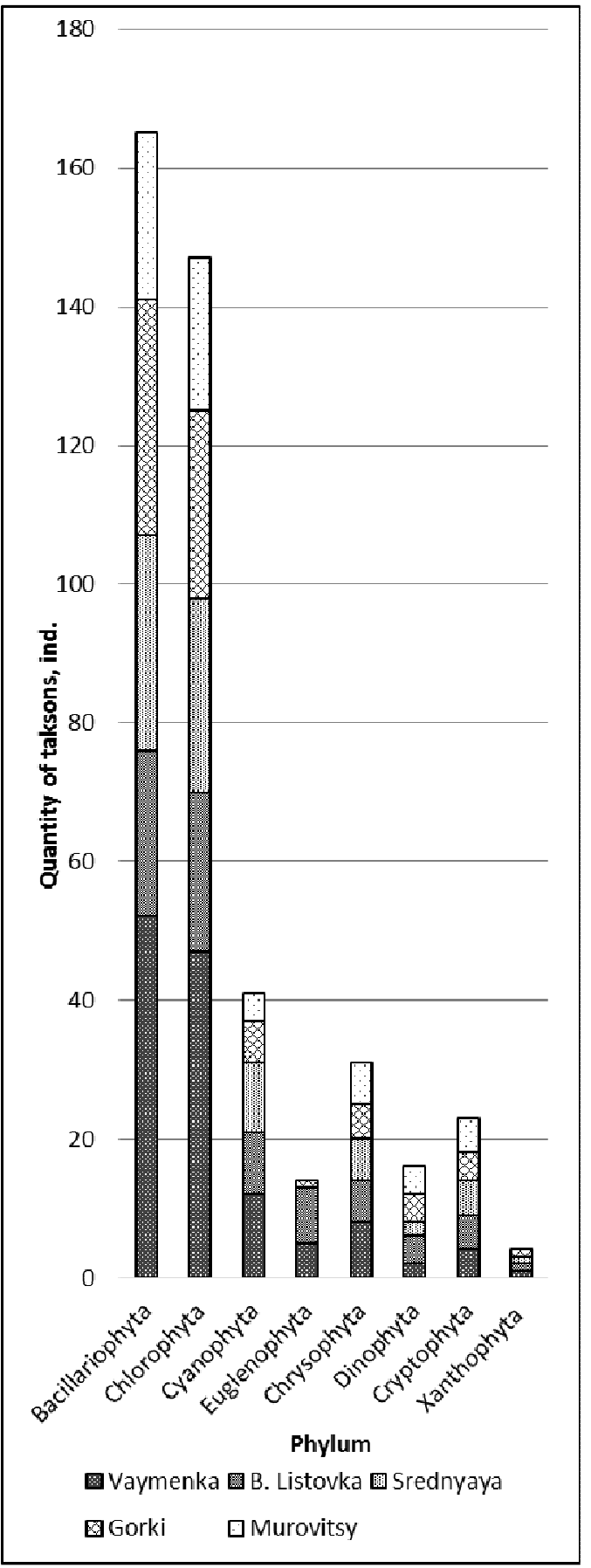

Fig. 2. Comparison of the taxonomic composition of phytoplankton in different sampling points in Delta
By the nature of the geographical distribution for algal flora of Velikaya river delta was characteristic absolute dominance of cosmopolitan forms $(86.3 \%$ of the number of taxa that had data). By habitat most of the taxa belonged to plankton $(43.6 \%)$ and planktonic-benthic $(34.6 \%)$ forms. Benthos (17.6\%) and fouling $(4.2 \%)$ algae represented significantly less.

Table 3

Ecological and Geographical Characteristics of Phytoplankton Velikaya River Delta

$(\chi$-xenosaprobionts, $o$ - oligosaprobionts, $\beta$ - betamezosaprobionts, $\alpha$ - alpha- mezosaprobionts, $\mathrm{p}-$ polysaprobionts)

\begin{tabular}{|c|c|c|}
\hline Parameter & $\begin{array}{l}\text { Number of } \\
\text { species }\end{array}$ & $\begin{array}{c}\% \text { of the total } \\
\text { number }\end{array}$ \\
\hline \multicolumn{3}{|l|}{ Distribution: } \\
\hline Cosmopolitans & 107 & 86.3 \\
\hline Boreal & 9 & 7.3 \\
\hline Holarctic & 6 & 4.8 \\
\hline Circumboreal & 1 & 0.8 \\
\hline Arctic & 1 & 0.8 \\
\hline Total: & 124 & 100 \\
\hline \multicolumn{3}{|l|}{ Habitat: } \\
\hline Planktonic & 72 & 43.6 \\
\hline Planktonic-benthos & 57 & 34.6 \\
\hline Benthos & 29 & 17.6 \\
\hline Fouling & 7 & 4.2 \\
\hline Total: & 165 & 100 \\
\hline \multicolumn{3}{|l|}{ Halobility: } \\
\hline Indifferent & 88 & 76.5 \\
\hline Halophyles & 16 & 13.9 \\
\hline Halophobs & 6 & 5.3 \\
\hline Oligogalobs & 5 & 4.3 \\
\hline Total: & 115 & 100 \\
\hline \multicolumn{3}{|l|}{ Related to $\mathrm{pH}$ : } \\
\hline Indifferent & 47 & 47.9 \\
\hline Acidophile & 5 & 5.1 \\
\hline Alkaliphile & 42 & 42.9 \\
\hline Alcalibionts & 4 & 4.1 \\
\hline Total: & 98 & 100 \\
\hline \multicolumn{3}{|l|}{ Saprobity: } \\
\hline$\chi$-o- saprobionts & 1 & 0.8 \\
\hline$\chi-\beta$ - mezosaprobionts & 2 & 1.6 \\
\hline oligosaprobionts & 8 & 6.6 \\
\hline o- $\beta, \beta$-o-saprobionts & 20 & 16.4 \\
\hline$\beta$ - mezosaprobionts & 54 & 44.3 \\
\hline o- $\alpha$ - mezosaprobionts & 15 & 12.3 \\
\hline$\alpha-\beta, \beta-\alpha$ - mezosaprobionts & 13 & 10.7 \\
\hline$\alpha$ - mezosaprobionts & 7 & 5.7 \\
\hline$\alpha$-p, p- $\alpha$ - mezosaprobionts & 2 & 1.6 \\
\hline Total species indicators & 122 & 100 \\
\hline Mean Pantle-Bukk index & & \\
\hline
\end{tabular}

All taxa in relation to water mineralization were oligohalobs. Of those prevailed indifferent - 76.5\%, while the share of halophiles and halofobs represented up to $13.9 \%$ and $5.3 \%$ respectively. 
A comparison of the taxonomic composition of phytoplankton of the Velikaya river delta with a list of algae-indicators of organic pollution [22] revealed the predominance of beta- mezosaprobionts $(44.3 \%)$ which are indicators of moderate water pollution. $25.4 \%$ of total algae are inhabitants of clean water. One of detected species is xenooligosaprob Sellaphora bacillum (Ehr.) $18 \%$ of the total number of indicator species are Mann. Microalgae, which preferred contaminated water including 2 species inhabitants of polluted water - euglenophytes Colacium cyclopicola (Gickl.) Woronich. et Popova and Euglena proxima P.A.Dangeard.

Water quality assessment by Pantle - Bukk index in Sladecheka modifications identified $\beta$ mesosaprobic nature of waters in the Velikaya river delta, which allowed to attribute them to a category of moderately polluted water. The calculated saprobity indexes ranged from 2.0 to 2.2. The highest values of Pantel - Bukk index are noted at sampling points "B. Listovka" and "Gorki" (2.2).

The comparison of floristic composition of the Velikaya river delta with the studies of past years [5] shows that 57 and 33 taxa of phytoplankton were found in summer periods from 1992 to 2000 in delta, while in 2016165 taxa were identified. This may result from a number of factors. Firstly, in 1992 difficult economic situation led to termination of work at Pskov enterprises, which consequently partially affected the cleanliness of water in the delta and as a result promoted an increase of biodiversity of phytoplankton. Secondly, in recent years there has been acceleration of eutrophication processes in the Peipus lake, leading to the "algal bloom" in the waterbody, starting from the beginning of summer. It reveals itself by an increase of nutrients in water that cause the intensification of microalgae growth. Nowadays, in comparison with previous years, there is a significant overgrowth of the Delta by macrophytes therefore samples show a lot fouling and benthic forms in addition plankton forms (Tab. 2).

In general, the observation of the area during the studied period proves that the basis of phytoplankton is diatomaceous-green algaecomplex.

Saprobiological analysis revealed no significant changes of values saprobity index since 1992 (Tab. 4). The waters of Velikaya river delta can be characterized as moderately polluted.

Table 4

Comparison of Values Saprobity Index in Different Years (Summer Season)

\begin{tabular}{|l|c|}
\hline Years & Value of Pantle-Bukk index \\
\hline 1992 & $1.9-2.2$ \\
\hline 2000 & $1.7-2.2$ \\
\hline 2001 & $2.3-3.5$ \\
\hline 2016 & $2.0-2.2$ \\
\hline
\end{tabular}

The maximum values of Pantle-Bukk index have been observed in points "B. Listovka" and "Gorki" (2.2). The lowest value of index marked for point
"Srednaya" (2.0). Generally, the index value at the sampling points did not differ significantly, which characterizes the delta area as relatively homogeneous territory by content organic pollutants.

For the analysis of the alpha-diversity of phytoplankton Velikaya river delta were used Shannon index, Simpson index, Margalef index and Pielou evenness index. The results of calculations for the sampling points are presented in Tab. 5 .

The greatest value of Shannon index is characterized by a microalgae community of point "Vaymenka" $(\mathrm{H}=3.36)$, which indicate maximum number of its species and absence among them expressed dominants. The smallest information diversity was typical for point "Srednaya» $(\mathrm{H}=2.92)$. In general, the values of Shannon indices indicate the average complexity structure of microalgae communities in Velikaya river delta.

Table 5

Values of Biological Diversity Indices (H - Shannon Index; E pielou's evenness index; $\mathrm{C}$ - simpson index; $\mathrm{d}$ - margalef index)

\begin{tabular}{|l|c|c|c|c|}
\hline $\begin{array}{c}\text { Sampling } \\
\text { points }\end{array}$ & $\mathrm{H}$ & $\mathrm{E}$ & $\mathrm{C}$ & $\mathrm{d}$ \\
\hline Vaymenka & 3.36 & 0.78 & 0.06 & 5.96 \\
\hline B. Listovka & 3.11 & 0.78 & 0.07 & 4.60 \\
\hline Srednaya & 2.92 & 0.71 & 0.11 & 5.40 \\
\hline Gorki & 2.98 & 0.70 & 0.11 & 6.01 \\
\hline Murovici & 2.94 & 0.73 & 0.12 & 5.05 \\
\hline Average & 3.06 & 0.74 & 0.09 & 5.41 \\
\hline
\end{tabular}

Margalef index reflects the density of species, or species richness, in a certain area, i.e. the higher index value the even larger species richness characterized this territory. The largest value of Margalef index was observed at the study point "Vaymenka» $(\mathrm{d}=5.96)$, and the least was in point "B. Listovka» $(\mathrm{d}=4.60)$. Overall, values of Margalef index characterized Velikaya river delta as an area of high species richness.

Simpson index indicates the dominance of certain species in community. All investigated delta areas are characterized by extremely low values of Simpson index, which characterizes them as a communities with unexpressed dominant species.

Values of Pielou index were almost identical and had quite high values and as in case of Simpson index indicates high evenness of communities structure.

In the analysis of similarity of species composition algal communities of different sampling points of delta using Sørensen index the highest degree of similarity was found between points "Gorki" and "Murovitsy» (Ics = 0.82), the lowest between points "Vaymenka" and "B. Listovka» (Ics = 0.57). In general, the degree of similarity between compared areas was high. Common to all five points studied were 30 species, most of which belonged to green algae and diatoms. 
For comparison communities microalgae of Velikaya river delta by species composition was used procedure of cluster analysis was used. As a joining method was applied Ward method, This method is minimum variance criterion minimizes the total within-cluster variance, i.e. it creates the most compact cluster on degree of similarity between group members. The material for cluster analysis were the samples obtained from the delta's areas.

By peculiarities of species structure all sampling points of the delta is clearly divided into two clusters, one of which is represented by points "Vaymenka" and "Srednaya", and the other - points "Murovitsy", "Gorki" and "B. Listovka". The singularity of the species structure indicates that despite relatively small square of ecosystem of Velikaya river delta, it is different certain structural heterogeneity due to nature of currents, hydrochemical and hydrophysical characteristics, and the heterogeneity of input and migration of allochthonous substances of antropogenic origin (Fig. 3).

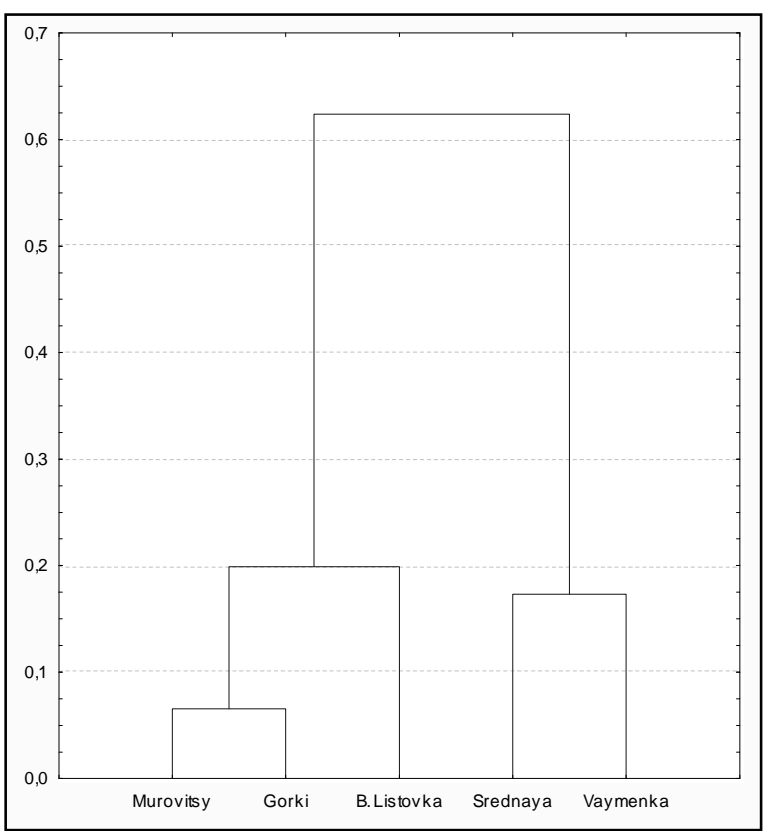

Fig. 3. Dendrogram similarities of species structure of phytoplankton communities of the Velikaya river delta

\section{CONCLUSION}

1. Hydrochemical analysis showed that waters of Velikaya river delta are carbonate-calcium, with a high content of nitrogen-ions group, indicating that active processes of organic matter mineralization.

2. The phytoplankton of the Velikaya river delta in summer period 2016, was represented by 165 species of taxa below rank of genus, belonging to 8 phylums, 11 classes, 18 orders, 43 families, 90 genera.

3. Ecological and geographical analysis of phytoplankton demonstrates that the Velikaya River Delta is dominated by freshwater, widespread, planktonic species preferring alkalescent water.

4. Data of saprobiological analysis shows moderate pollution of studied areas of the Velikaya river delta, which can be attributed to III water quality class.

5. The ecosystem of the Velikaya River Delta is characterized by relatively high species richness, average complexity of structure of its constituent algae communities, and high evenness of species, indicating relative stability of ecosystem. Comparison of species composition of phytoplankton communities in different parts of the Delta shows a fairly high degree of similarity (Ics $=0,57-0,82$ ). Identification of differences in structure of communities of species proves the existence of ecological differentiation in microalgae complexes resulting from heterogeneity of delta.

\section{REFERENCES}

[1] Stefano Pagiola, Elías Ramírez, José Gobbi, Cees de Haan, Muhammad Ibrahim, Enrique Murgueitio, Juan Pablo Ruíz. Paying for the environmental services of silvopastoral practices in Nicaragua // ECOLOGICAL ECONOMICS 64 (2007) P. 374-385. Available at: DOI 10.1016/j. ecolecon.2007.04.014. [Accessed: Feb. 27, 2017].

[2] Nathanial Matthews. People and Fresh Water Ecosystems: Pressures, Responses and Resilience // Aquatic Procedia. Volume 6, August 2016, Pages 99-105. Available at: DOI 10.1016/j.aqpro.2016.06.012. [Accessed: Feb. 27, 2017]

[3] Junguo Liu, Giri Kattel, Hans Peter H. Arp, Hong Yang. Towards threshold-based management of freshwater ecosystems in the context of climate change // Ecological Modelling, Volume 318, 24 December 2015, Pages 265-274. Available at: DOI 10.1016/j.ecolmodel.2014.09.010. [Accessed: Feb. 27, 2017].

[4] Millenium Ecosystem Assessment Series. Ecosystems and human well-being: wetlands and water synthesis. Washington, D.C.: Island Press, 2005. 63 p.

[5] Environmental monitoring of the Velikaya river delta. Part I / ed. O.A. Lebedeva. Pskov. PSPI, 2003. 156 p.

[6] Shitikov V.K. Zinchenko T.D., Rosenberg G.S. Macroecology of river community: concepts, methods, models. Togliatti: Cassandra, 2011. 255 p.

[7] GOST 31957-2012 Water. Methods for determination of alkalinity and mass concentration of carbonates and bicarbonates. Moscow, 2013. 25 p.

[8] GOST 31861-2012 Water. General requirements for sampling. Moscow, 2014. 63 p.

[9] Environmental normative document (Federal)14.1:2:4.3-95 Methods of measurement of mass concentration of nitrite ions in drinking water, surface water and sewage of photometric method with Griess reagent. Moscow, 1995 (edition 2011). $17 \mathrm{p}$.

[10] Environmental normative document (Federal)14.1:2:4.4-95 Methods of measurement of mass concentration of nitrate ions in drinking water, surface water and sewage of photometric method with salicylic acid. Moscow, 1995 (edition 2011). 13 p.

[11] Environmental normative document (Federal) 14.1:2:4.50-96 Methods of measuring the total mass concentration of total iron in drinking water, surface water and sewage of photometric method with sulfosalicylic acid. Moscow, 1996 (edition 2011). 17 p.

[12] Environmental normative document (Federal) 14.1:2:4.11297 Methods of measurement of mass concentration of phosphate ions in drinking water, surface water and sewage 
Environment. Technology. Resources, Rezekne, Latvia Proceedings of the $11^{\text {th }}$ International Scientific and Practical Conference. Volume I, 82-88

by the photometric method with ammonium molybdate. Moscow, 1997 (edition 2011). 13 p.

[13] Environmental normative document (Federal)14.1:2:3:4.12397 Methods of measurement of the biochemical oxygen demand after the n-days of incubation (BOD full) in surface freshwater, groundwater, drinking water, sewage and effluent sewage. Moscow, 1997 (2004 edition.) 34 p.

[14] Environmental normative document (Federal) 14.1:2:4.2762013 Methods of measurement of the mass concentration of ammonia and ammonium ions in drinking water, natural water and sewage by photometric method with Nessler reagent. M., 2013. 14 p.

[15] Algae. Handbook / Wasser S.P., Kondratieff N.V., Masuk N.P. Kiev, "Nauk. Dumka", 1989. 608 p.

[16] Masuk N.P. Methods of collecting and study of algae / N.P. Masuk, M.I. Radchenko // Algae: Guide. By ed. S.P. Wasser. Kiev "Nauk. Dumka", 1989, pp. 170-188.

[17] Methods of study of inland waters ecosystems. / By ed. F.D. Mordukhay-Baltovski. Moscow. Nauka. 1975. 240 p.

[18] Carenko P.M. Summary determinant Chlorococcaceae algae of Ukrainian SSR / USSR Academy of Sciences. Institute of Botany named N.G. Kholodny. By ed. G.M. PalamarMordvintseva. Kiev, "Nauk. Dumka", 1990. 208 p.

[19] Komárek J., Anagnostidis K. Cyanoprokaryota 1. Teil: Chroococcales // Süsswasserflora von Mitteleuropa. Bd. 19/1. Jena; Stuttgart; Lübeck; Ulm. 1998. 548 s.
[20] Krammer K., Lange-Bertalot H. Bacillariophyceae. Teil 3. Centrales, Fragilariaceae, Eunotiaceae // Ibid. Stuttgart. 1991. Bd. 2/3. S. 1-576.

[21] Krammer K., Lange-Bertalot H. Bacillariophyceae. Teil 1. Naviculaceae // Die Süsswasserflora von Mitteleuropa. Stuttgart. 1986. Bd. 2/1. S. 1-876.

[22] Komárek J., Anagnostidis K. Cyanoprokaryota. 2 Teil: Oscillatoriales // Süsswasserflora von Mitteleuropa. Bd. 19/2. München. 2005. 759 s.

[23] Sadchikov A.P. Methods of studying freshwater phytoplankton: guide. Moscow, "University and school", 2003. 157 p.

[24] Barinova S.S., Medvedev A.L., Anisimova O.V. Biodiversity of algae-indicators. Tel Aviv, 2006. 498 p.

[25] Sudnitsyna D.N. Algae of waterbodies Pskov region. Pskov, "LOGOS Plus", 2012. 224 p.

[26] Sládeček V. System of water quality from biological point of view // Arch. Hydrobiol. Ergebn. Limnol. 1973. 7. P. 1-218.

[27] Schmidt V.M. Statistical methods in comparative floristry. Leningrad, 1980. 176 p.

[28] Khalafyan A.A. STATISTICA 6. Statistical data analysis: textbook. 3rd ed. Moscow, Binom, 2007. 512 p.

[29] Trifonova I.S. Ekology and lake phytoplankton succession. Leningrad, 1990. $184 \mathrm{p}$

[30] Assessment of ecological status of Lake Ladoga basin by hydrochemical parameters and structure hydrobiocenoses / By ed. I.S. Trifonova. Sankt-Petersburg., 2006. 130 p. 